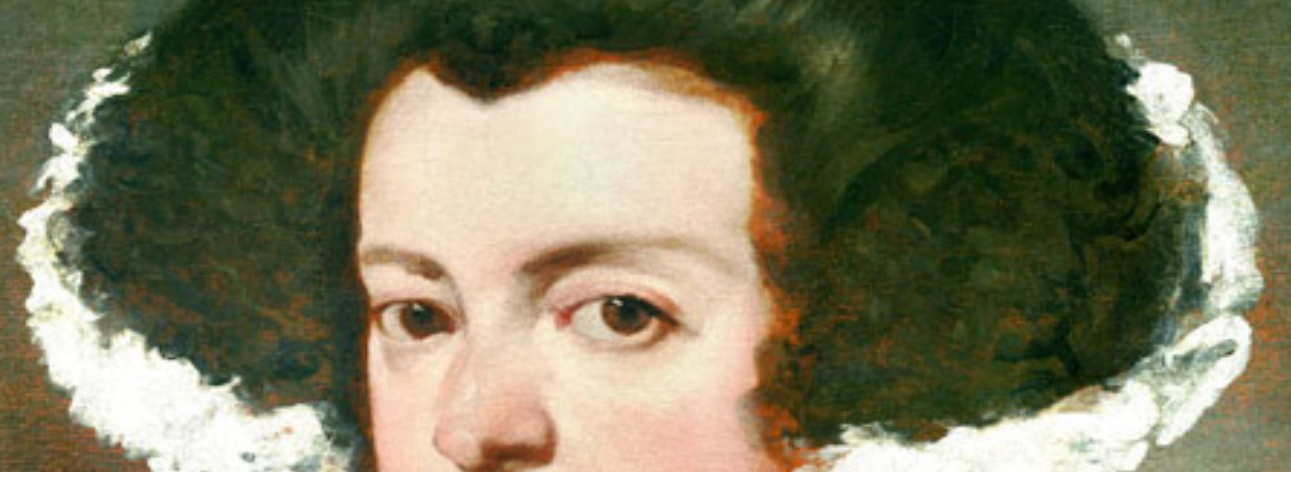

\title{
Diego Velázquez: Un retrato del natural de la Reina Isabel de Borbón
}

\section{Carmen Garrído Pérez}

Resumen: Entre las prácticas del pintor Diego Velázquez (Sevilla, 1599- Madrid, 1660), está la de realizar apuntes al óleo sobre lienzo "del natural", de aquellas personas de las que después haría retratos en otras dimensiones. En el catálogo de su obra existen esta clase de bocetos: rey Felipe IV, Infanta María Teresa o Baltasar Carlos. El de Isabel de Borbón que aquí se da a conocer viene a sumarse a los mencionados.

La inmediatez y la soltura técnica son las características más importantes de todos estos retratos, en los que el pintor ha centrado su trabajo en la captación del espíritu del personaje, de una manera que resulta más natural que las posteriores versiones que hará a partir de ellos. Debido a su finalidad, Velázquez se centra fundamentalmente en la cabeza, insinuando solamente otros detalles como el peinado, el posible atuendo o el fondo.

Todos los datos técnicos y estilísticos extraídos de este estudio de la Reina avalan la atribución al maestro sevillano.

Palabras clave: retrato de Isabel de Borbón; retrato de Velázquez; Estudio técnico de un retrato; autoría de Velázquez; boceto del natural.

\section{Diego Velázquez: A portrait of Queen Isabel de Borbón painted from life}

Abstract: One of the salient practices of Diego Velázquez (Sevilla, 1599- Madrid, 1660) was to make portrait oil studies from life of individuals that he would subsequently represent in other dimensions and formats. Among works of this type are portraits of king Philip IV, the Infanta María Teresa and the Infante Baltasar Carlos. The portrait sketch of queen Isabel de Borbón presented here is another such painting.

Immediacy and technical fluency count among the most important characteristics of these portraits; the painter has evidently concentrated his attention on capturing the "spirit" of the person and did so in a manner that appears more "natural" than subsequent versions of the image. Given the function of such images, Velázquez focuses almost exclusively on the head and merely implies details of the hairstyle, costume and the background.

The technical evidence and stylistic qualities of this study supports an attribution to the Sevillian master.

Key words: portrait of Elizabeth of Borbon; portrait of Velázquez; Technicalstudy of a portrait; Velázquezauthorship; sketch from life

\section{Diogo Velázquez: Um retrato do natural daRainha Isabel de Borbón}

Resumo: Resumo: Entre as práticas do pintor Diogo Velázquez (Sevilha, 1599- Madrid, 1660), figura a de realizar esboços a óleo sobre tela "do natural", daquelaspessoas de quemviria a fazer, mais tarde, retratos de outrasdimensões. No catálogo da sua obra existe esta classe de esbocetos: rei Filipe IV, Infanta Maria Teresa ou Baltasar Carlos. O de Isabel de Borbon que aqui se dá a conhecer, vem a somarse aos mencionados.

A imediatez e a soltura técnica são as características mais importantes de todos estes retratos, nos quais o pintor centrou o seutrabalhonacaptação do espírito da personagem, de uma forma que resulta mais natural que as versões posteriores que irá fazer, a partir 
destes. Tendoemconta a suafinalidade, Velásquez, centra-se fundamentalmente nacabeça, apenas insinuando outrosdetalhes, como o penteado, o eventual vestuárioou o fundo.

Todos os dados técnicos e estilísticos extraídos desteestudo sobre a rainhaatestam a atribuiçãoaomestresevilhano.

Palavras-chave: retrato de Isabel de Borbon; retrato de Velázquez; Estudotécnico de um retrato; autoria de Velázquez;esboceto do natural

La Reina Isabel de Borbón (1602-1644) fue la primera esposa del Rey de España Felipe IV (1605-1665), hijo del Rey Felipe III y de la Reina Margarita, cuyo reinado transcurrió entre los años 1621 y 1665 . Era hija de Enrique IV de Francia y de María de Medicis y se desposó en 1615 con Felipe IV, siendo aún Príncipe de Asturias, y por tanto heredero al Trono.

Aunque existen retratos de la Reina de otros pintores de la Corte como Rodrigo de Villadrando, Francisco Rizzi o Frans Pourbus, no son tantos los que conocemos actualmente pintados por Diego Velázquez. Hay pocas imágenes de ella que fueron repetidas, en ocasiones, varias veces por otros maestros menos dotados ${ }^{~}$. Tal vez, en esta escasez de representaciones pueda haber influido la idea transmitida por las crónicas sobre lo poco que le gustaba posar: "decía que no se dejaba retratar de buena gana" (Oliván 2012:1635; Doval 2009: 137-157).

El cuadro que aquí examinamos es un estudio de la cabeza de Isabel de Borbón (Óleo sobre lienzo, 73 x 59 cm), tomado del natural, de los que éste y otros pintores solían hacer como modelos del personaje antes de abordar la ejecución de la imagen definitiva (Fig.1). Bernardino de Pantorba en el año 1960 dio a conocer este prototipo en un cuaderniIlo, atribuyéndolo a Velázquez, y datándolo entre 1631-32, cuando la Reina tenía unos treinta años (Pantorba 1960).

La ejecución de retratos partiendo del boceto de la cabeza es un procedimiento que ya nos describe Francisco Pacheco, suegro de Velázquez, como punto de partida esencial para poder realizar posteriormente la pintura definitiva (Pacheco 1990). Este método tradicional fue empleado por grandes maestros de todos los tiempos, como por ejemplo los realizados por Goya entre mayo y junio de 1800 en Aranjuez para el Retrato de la familia de Carlos IV del Museo del Prado². Para la toma de estos modelos, los personajes posaban, y de ahí el naturalismo que emerge de manera especial en estas representaciones. Como decía Sebastiano Ricci en un comentario sobre las pinturas religiosas, «el boceto es la obra terminada y el cuadro de altar la copia», lo que podría aplicarse igualmente al género del retrato.

Desde el principio, Velázquez siguió los consejos de Pacheco, y tenía «cohechado un aldeanillo aprendiz, que le servía como modelo en diversas acciones y posturas». Ya
Queen Isabel de Borbón (1602-1644) was the first wife of the King of Spain, Philip IV (1605-1665), son of King Philip III and Queen Margarita, who reigned from 1621 to 1665. The daughter of King Henry IV of France and Maria de Medici, Isabel married Philp IV in 1615 whilst he was still the Prince of Asturias and heir to the throne.

Although there are portraits of the Queen by other court painters such as Rodrigo de Villandrando, Francisco Ric$\mathrm{ci}$ and Frans Pourbus, at the current time we know of very few painted by Velázquez. There are also a number of depictions of Isabel which were repeatedly copied by less capable artists '. Historical accounts suggest that the Queen did not enjoy sitting for her portrait - "it was said that she did not allow herself to be painted with any great desire." - and this may account for the scarcity of such representations (Oliván 2012:16-35; Doval 2009: 137-157).

The painting under examination here is a study of the head of Isabel de Borbón that has been painted from life (fig. 1; oil on canvas, $73 \times 59 \mathrm{~cm}$.). It is the type of study that Velázquez and other artists made as models before painting the finished portrait. In 1960, Bernardino de Pantorba published the picture in a pamphlet with an attribution to Velázquez and dated it to 1631-2, when the Queen was 30 years old. (Pantorba 1960)

The execution of a portrait based on a sketch of the sitter's head is a practice described by Francesco Pacheco, Velázquez's father-in-law, as an essential starting point in being able to complete the finished picture at a later time. (Pacheco 1990). This is a traditional procedure followed by great artists throughout the ages, such as the studies painted by Goya in Aranjuez between May and June 1800 for the Portrait of the Family of Charles V (Museo del Prado, Madrid)2. To create these models, the figures would pose in person for the artist; this direct encounter is reflected in the striking naturalism evident in such depictions. As Sebastiano Ricci said in an essay on religious paintings: "the bozzetto is the finished work and the altarpiece the copy" - a comment that could apply equally to the genre of portraiture.

From the beginning, Velázquez followed Pacheco's advice, and "hired a village apprentice, whom he used as a model in a variety of actions and poses." Even during his 


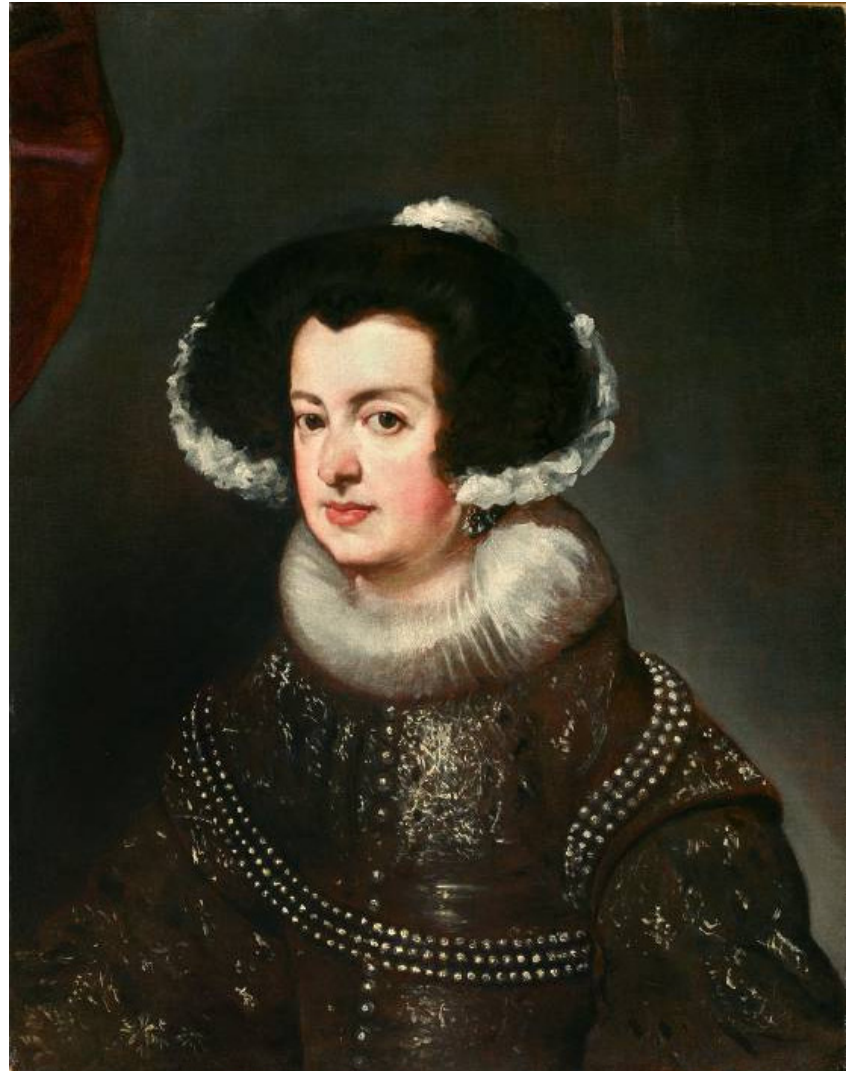

Figura 1. La Reina Isabel de Borbón. Colección particular.

en sus primeros años en la Corte, era tal su destreza en este sentido, que al comentarle el rey Felipe IV [...] «que no faltaba, quien dijese, que toda su habilidad se reducía a saber pintar una cabeza; a qué respondió: Señor, mucho me favorecen, porque yo no sé, que haya quien la sepa pintar», según cuenta Palomino en la biografía dedicada al pintor sevillano (Palomino 2008).

El examen de las imágenes radiográfica e infrarroja de la obra revelan el trabajo realizado por el pintor para la puesta en escena de la Reina, y la elaboración interna-externa necesaria para llevarla a cabo ${ }^{3}$. Este trabajo es el mismo, como se ha podido comprobar, al encontrado en muchas otras obras del autor ${ }^{4}$.

En primer lugar, sobre la preparación el artista marcó las líneas básicas de dibujo a fin de encajar la figura en el espacio, como se observa en el grueso trazo negro que bordea el peinado, en una ubicación superior a la que después se pintó. En el infrarrojo aparece esta línea por encima del adorno blanco que engalana su peinado (Fig.2). Otros trazos negros señalan el contorno de la cara, según vemos en el lateral derecho de la misma, bajando por el borde de la gola y marcando su límite en el lado contrario. Igualmente estas pinceladas de dibujo están en algunos perfiles del traje, en la manga izquierda al desplazarse hacia el exterior, y en la derecha, así como en torno al lugar por el que discurre el amplio diseño del adorno de las tres filas de perlas.

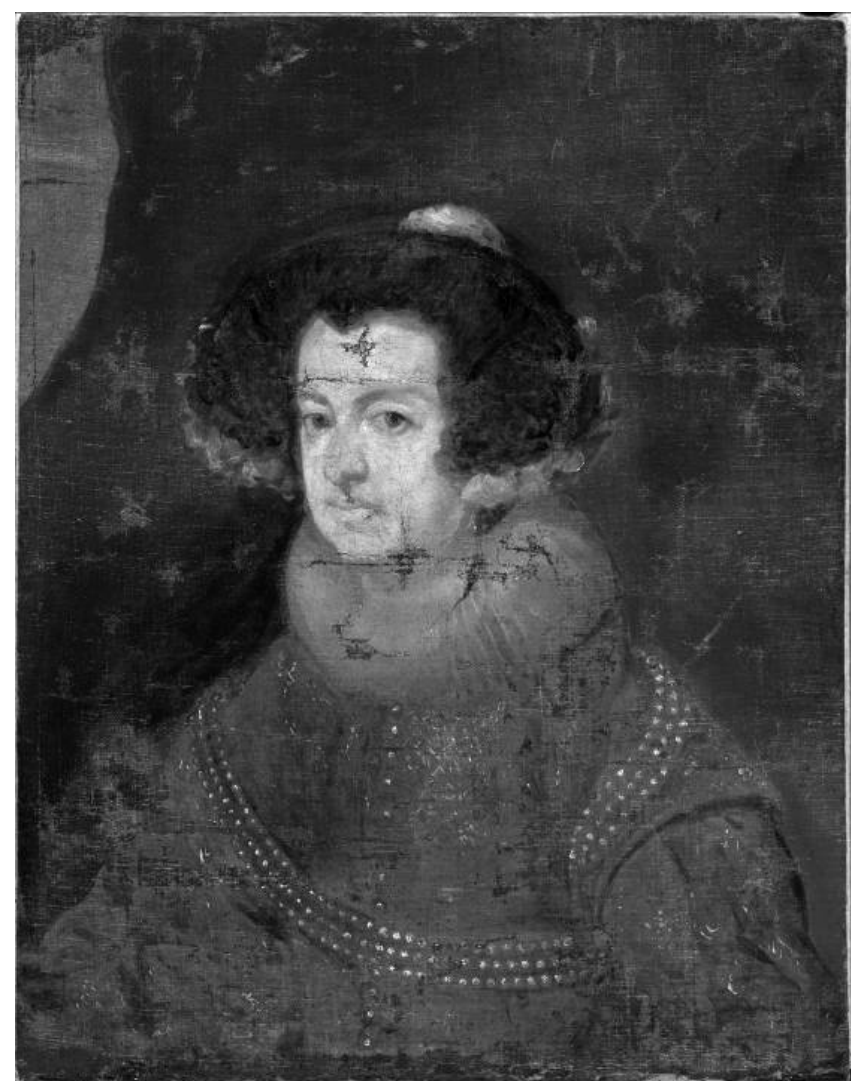

Figura 2. Imagen infrarroja del retrato.

early years at court, such was his ability in this regard that, according to Palomino in his biography of the artist, when King Philip IV commented that "... there are people who say that the essence of your skill is your ability to paint a face," Velázquez replied: "you favour me greatly, my Lord, because I do not know anyone who is able to do this." (Palomino 2008)

Examination of the x-radiograph and infra-red reflectogram of the portrait shows how the artist has established the subject on the canvas and the creative process employed in order to bring the portrait to completion ${ }^{3}$. As has been demonstrated, this process is the same as that found in many other works by Velázquez ${ }^{4}$.

The artist began by drawing the basic strokes to position the figure within the pictorial space, as can be seen in the broad black line around the top of the sitter's hair, showing too that this was originally higher than it was eventually painted. In the infra-red reflectogram, this line appears above the white net which adorns the hair (Fig. 2). Additional strokes of black define the outline of the face, as can be seen on the right side, running down the border of the ruff and marking its outer edges. Similarly, this brush drawing can be seen in some of the contours of the costume, and in both the right sleeve and left (as it turns towards the viewer), as well as the area occupied by the three strings of pearls. The shape 
También, de manera simplificada deja intuir la forma del vestido y los pliegues formados por la tela en su caída por la manga izquierda. A través de todos ellos, el maestro precisa las líneas del esquema general.

Las características del gesto y la grafía del somero dibujo se corresponden con los que Velázquez realiza habitualmente, tanto en sus cuadros acabados como en aquellos otros que al igual que éste son modelos para obras posteriores, según se constata en toda su carrera, por ejemplo el boceto para el Retrato de Baltasar Carlos a caballo del Museo del Prado que se conserva en la Galería Carrara (Bérgamo) o el también boceto de Felipe IV de última época del Museo del Prado, en el que el esquema de la creación artística sigue siendo el mismo (Fig. 3). Trazos de dibujo semejantes, aunque para prefijar detalles diferentes, son visibles directamente en obras sin terminar, como en el caso de la mano derecha del retrato de Hombre Joven (Pinacoteca de Múnich), o en el diseño de la escultura de la cabeza de Felipe IV en el retrato de Juan Martínez Montañés del Museo del of the dress and the folds in the fabric of the left sleeve are also sketched-in in the same abbreviated manner. In this way, the artist defined the overall composition of the portrait.

The graphic character of the summary preliminary drawing is consistent with Velazquez's usual practice, both in finished works and in preparatory sketches such as the present portrait. This can be seen in paintings from all stages of the artist's career, such as the bozzetto in the Accademia Carrara, Bergamo, for the Portrait of Baltasar Carlos on Horseback (Museo del Prado, Madrid) or the study for the late Portrait of Philip IV (also in the Prado), which follows the same creative process (fig. 3). Similar brush drawing, albeit to establish different details, is visible to the naked eye in unfinished works - see, for example, the right hand of the sitter in the Portrait of a Young Man (Alte Pinakothek, Munich), or the sketched sculpture of the head of Philip IV in the Portrait of Juan Martínez Montañés in the Museo del Prado (Ga-
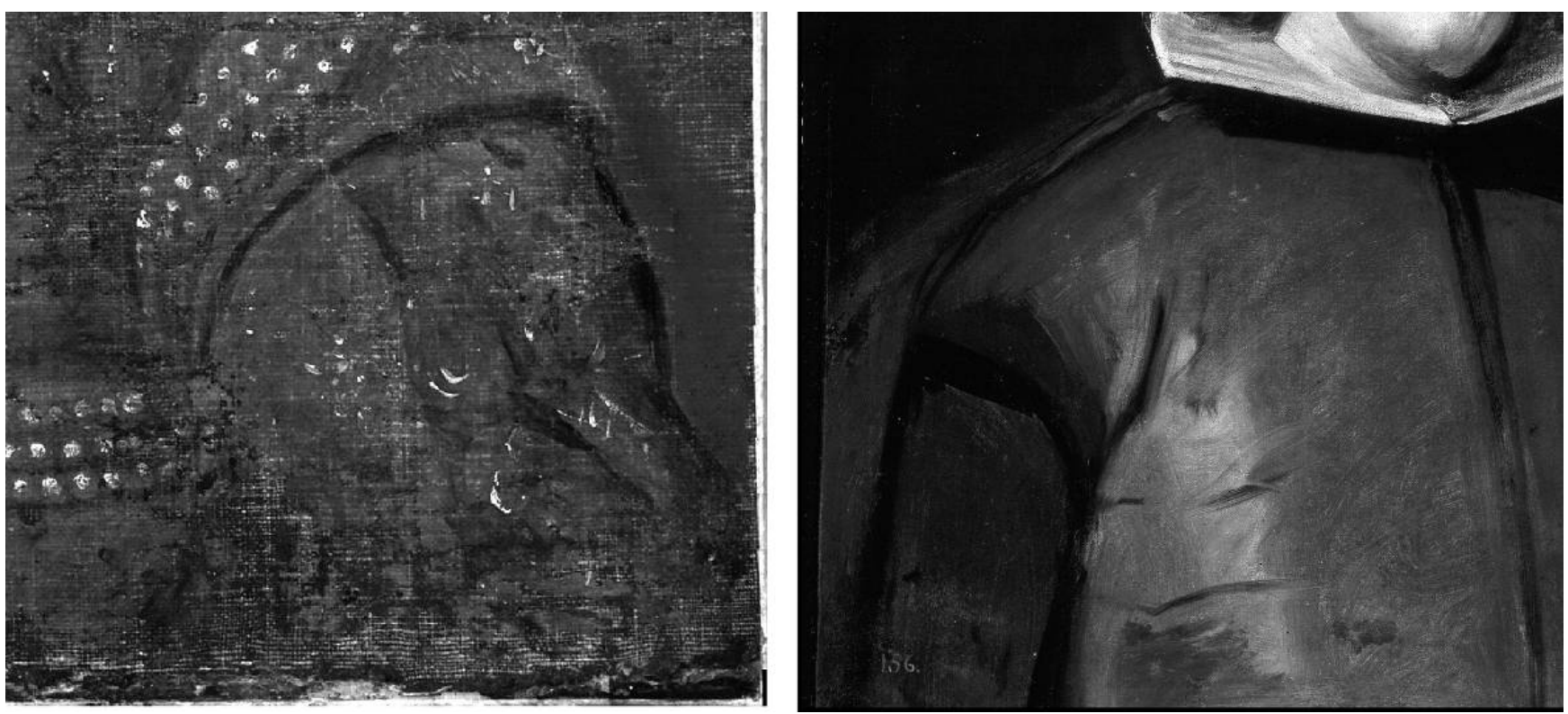

Figura 3. Comparación del dibujo de puesta en escena del retrato de la Reina con el retrato de Felipe IV, dos décadas posterior. Reflectografía infrarroja de la Reina y visible en blanco y negro del Rey.

\section{Prado (Garrido 1992).}

El infrarrojo también revela otras pinceladas negras, que, junto con las de color blanco, sugieren someramente los detalles decorativos del vestido, a la vez que nos permiten precisar un poco más la manera rápida y deshecha con la que Velázquez pintó el peinado de la Reina y algunas rectificaciones del cuello y del traje. Una imagen del cuadro, modificada con tratamiento digital a través de la saturación del color, completa esta información y ayuda a la interpretación de los dos documentos técnicos mencionados (Fig. 4). rrido 1992).

The infra-red image also reveals other brushstrokes of black which, along with brushstrokes in white, describe in an abbreviated fashion the decorative details of the sitter's dress. The reflectogram also allows us to observe more clearly the rapid, loose manner with which Velázquez has painted the hair and some of the changes he has made to the collar and costume. An image of the painting that has been digitally modified through colour saturation, and which can be compared to the x-ray and infra-red reflectogram, confirms these observations regarding the creative process (fig. 4). 


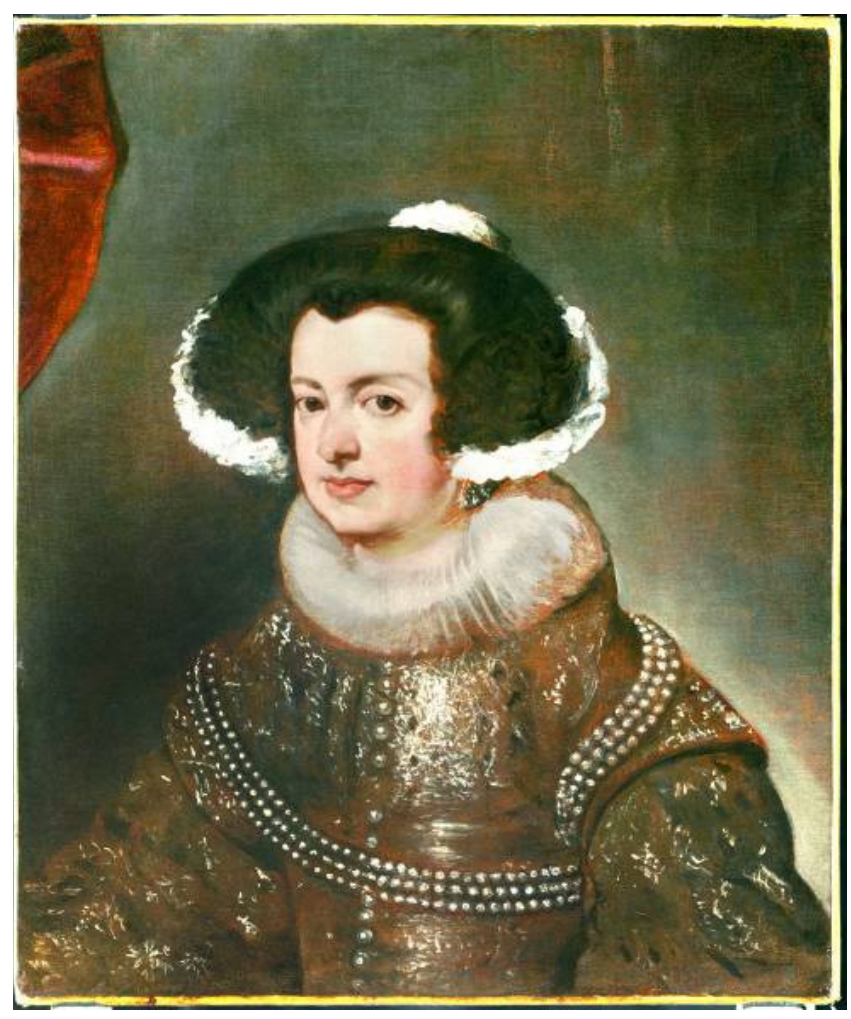

Figura 4. Imagen modificada con tratamiento digital.

La radiografía manifiesta el acusado contraste de la pintura con respecto al fondo, debido al proceso creativo del artista (Fig.5). Esta manera de trabajar es la que encontramos en las obras de sus etapas sevillana y madrileña. Después, poco a poco, las figuras se irán fundiendo con los fondos a causa del cambio que sufren los materiales empleados en las preparaciones de los lienzos, que pasan de la Tierra de Sevilla (de color ocre) usada en sus inicios, a la Tierra de Esquivias (de color naranja-rojizo) que se encuentra en sus primeros años de Madrid. Ambas carecen de radiopacidad frente a las que se hacen con albayalde como pigmento fundamental a partir de su primer viaje a Italia (1629-1631). El modelado de las figuras también irá cambiando, las capas de pintura serán cada vez más ligeras y el resultado radiográfico no será tan nítido, al ir ganando en la visión radiográfica el fondo óptico sobre la imagen definitiva (Garrido 1992).

El trazo superficial que marca el borde inferior del rostro en el lado izquierdo y el arranque del pincel que señala el límite del cuello al lado contrario, así como la luz más suave de la parte inferior de dicho cuello, revelan la grafía del pintor, que se ve reflejada incluso en obras muy posteriores como el boceto de la Infanta María Teresa del Metropolitan Museum (Colección Jules Bache, Nueva York). En este último o en el de la misma infanta conservada también en el Metropolitan (Colección Robert Lehman, Nueva York) el trazo de luz del inicio del cuello, en el lado derecho, se alarga en vertical dada

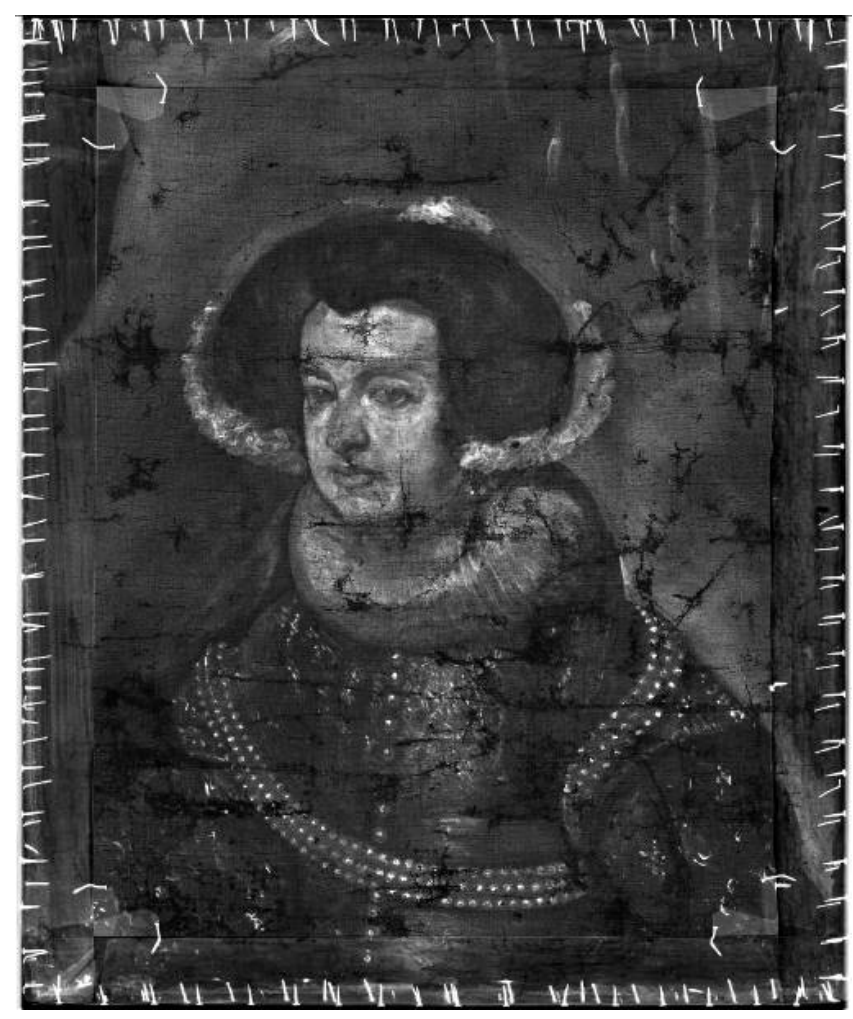

Figura 5. Radiografía general

The $x$-radiograph reveals the emphatic contrast between the figure and the background, which is the result of the artist's creative process (fig. 5). This way of working can also be found in paintings from Velázquez's Seville and Madrid periods. In later works, the figures tend to merge into the background because of the changes in the materials used to prepare the canvases - from the ochre of the 'Tierra de Sevilla' or 'Seville earth' ground used by the artist at the beginning of his career to the orange-red of the 'Tierra de Esquivias' or 'Esquivias earth' preparation found in the early Madrid works. Both of these types of ground lack the radiopacity of the grounds composed principally of lead white that Velázquez began to use on his first trip to Italy (162931). From this point, the modelling of the figures also begins to change; the layers of paint become progressively thinner such that the resultant $x$-ray image becomes less clear due to the increasing dominance of the background over the final image in the radiograph (Garrido 1992).

The topmost stroke of white that defines the lower edge of the face on the left side and the brushstroke indicating the line of the neck on the right, along with the softer lighting in the lower part of the neck, all reveal the hand of Velázquez. Such brushwork can also be seen in much later works by the artist, among them two preparatory studies for the Portrait of the Infanta María Teresa both in the Metropolitan Museum of Art, New York (Jules Bache collection and Robert Lehman collection), in which the stroke of light paint where the cheek meets the neck at the right hand side extends further upwards, in a more styli- 
su mayor estilización. En los cuellos de los personajes masculinos sucede algo similar: cuando quedan sin cubrir, dependiendo de si el cuello del retratado es corto o más largo, el arranque y desarrollo de estas pincela- zed manner. Something similar also occurs with the neck of the sitters in Velázquez's male portraits: when the neck is left exposed - depending on its length - the application and elaboration of the brushstrokes described above is the
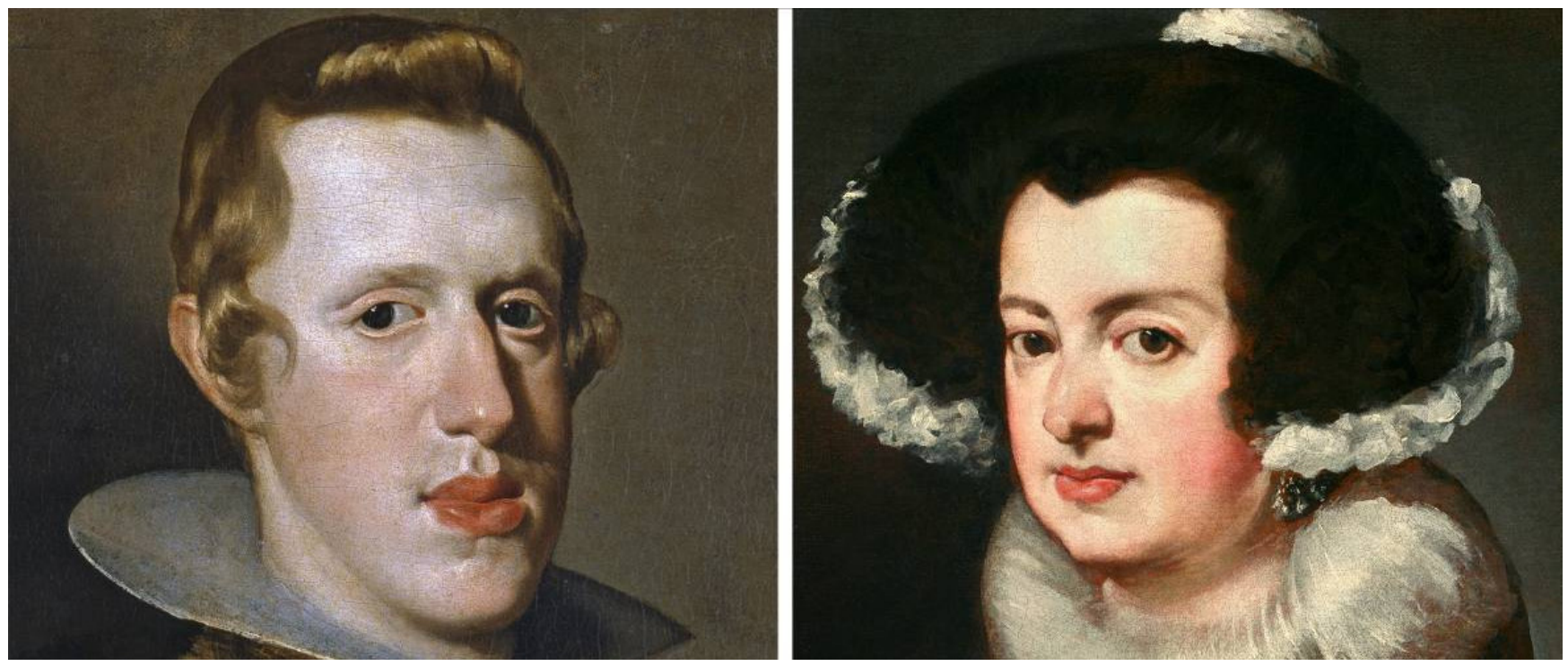

Figura 6. Comparación del retrato del rey Felipe IV con armadura con el de la Reina. El arranque de las pinceladas del inicio del cuello son similares, así como otros tratamientos de la superficie de la pintura.

das descritas son los mismos. (Fig.6)

La cabeza, por ser la zona más elaborada al tratarse de un estudio hecho del natural, está más empastada. El rostro se perfila respetando su lugar y encajándolo con el peinado según revela la radiografía. Este encaje va realizándose por aproximaciones del color, método que práctica Velázquez tanto en los retratos femeninos como en los masculinos, y en los personajes que integran sus composiciones, quedando siempre un pequeño espacio en el que el cabello queda más ligero sobre la carnación. Las capas de pintura más finas que cubren estos límites hacen que lo que se intuye en la imagen visible, en los documentos técnicos esté definido con mayor precisión, distinguiéndose la mancha o máscara inicial del rostro y su modelado posterior. En este modelado juega un papel muy importante la introducción de las luces a base de toques y trazos puntuales, como por ejemplo en los lacrimales, en los párpados y en las órbitas oculares, en donde el pincel se desliza con un ritmo circular, o bien mediante pinceladas más difusas en las mejillas y la frente, y toques menores en otras zonas a destacar de la cara. (Fig.7).

También es muy significativa la manera de hacer las sombras, que quedan enmarcadas por las luces que destacan con mayor intensidad en el documento radiográfico, práctica que encontramos en otros retratos y figuras pintadas por Velázquez. (Fig.8).

Otro recurso interesante es el de la ejecución del sombreado bajo la barbilla, la nariz o el hoyuelo de debajo de same (fig. 6).

There is a greater thickness of impasto in the face, since this is the most worked-up part of the portrait given that it is a study from life. As the x-ray reveals, the face is delineated within the space designated for it and fits closely under the hair - a fit achieved by the use of similar colours. This is a technique deployed by Velázquez in his portraits and in the figures in his larger compositions, where there is always a small area in which the hair is painted a little more thinly over the flesh tones. While thin layers of paint which cover the areas between the face and hair on the surface of the painting, the initial shape or silhouette of the face and its subsequent modelling can be seen more clearly in the $x$-ray and infra-red reflectogram. The use of highlights plays an important role in this modelling, ranging from precise dots and blobs of white in, for example, the lachrymals, eyelids and eyeballs, where the brush works in a circular movement, to broader strokes in the cheeks and forehead, and some smaller touches elsewhere that make the face stand out (fig. 7).

Also of great relevance is the way in which the shadows are formed, demarcated by the highlights which emerge more clearly in the $x$-ray image, a feature we see in other portraits and figures painted by Velázquez. (fig. 8).

Equally significant is the execution of the shadows under the chin, nose and lower lip. Although they are 

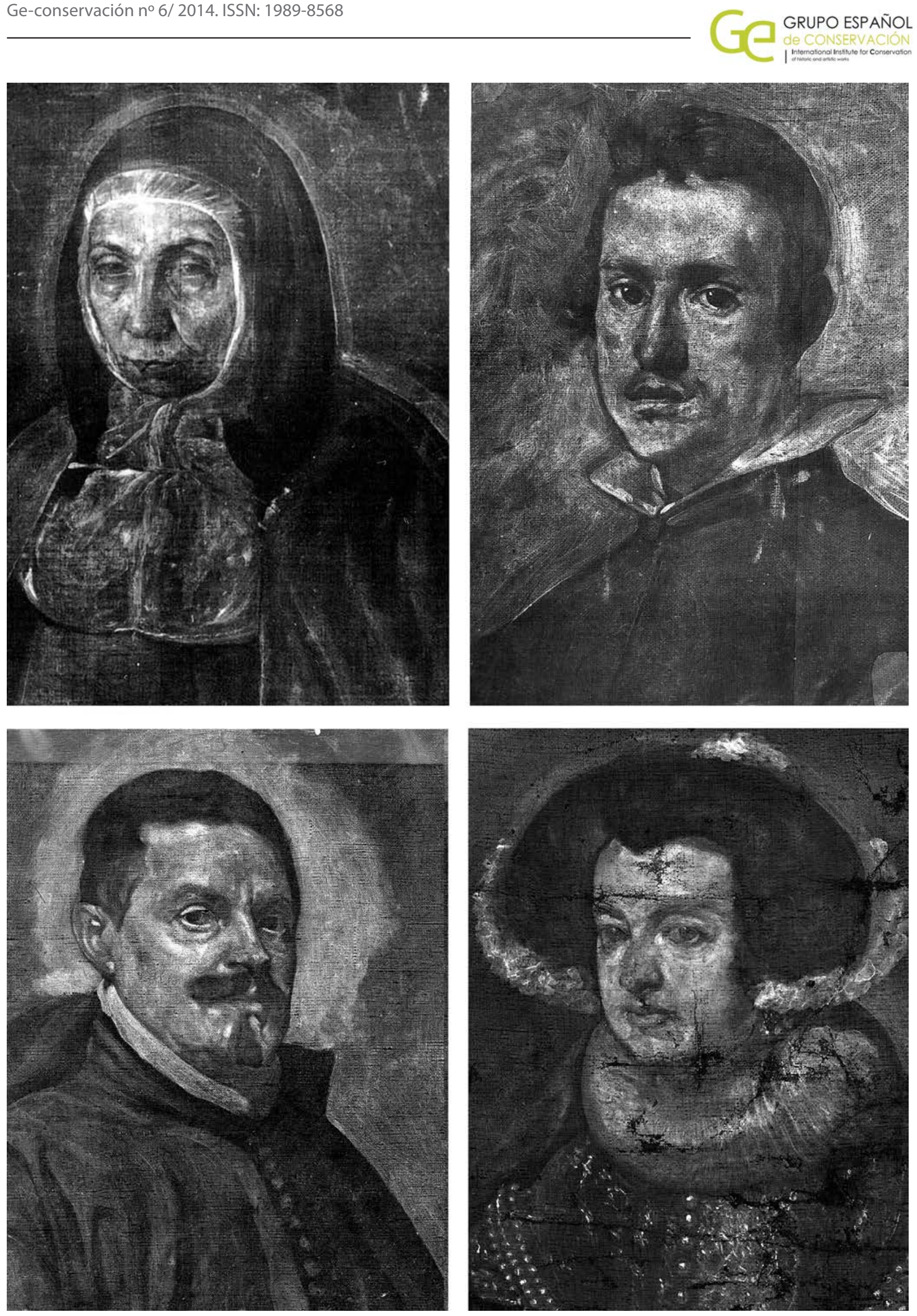

Figura 7. Detalles radiográficos de retratos de la década de los años veinte, cada uno con sus peculiaridades. En ellos destacan las diversas pinceladas introducidas por el pintor para resaltar las luces y los contornos. 


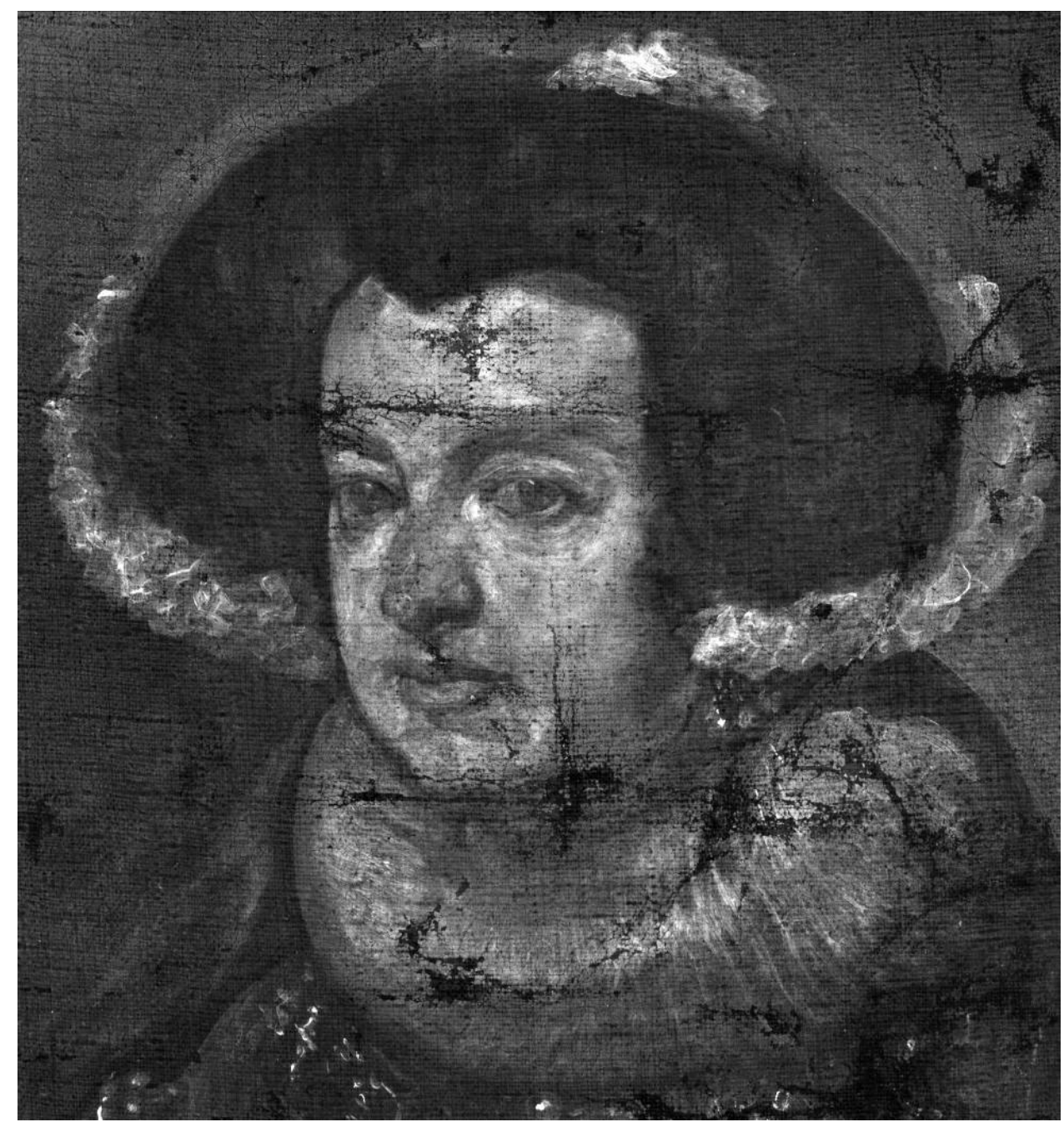

Figura 8. Detalle radiográfico de la cabeza de la Reina.
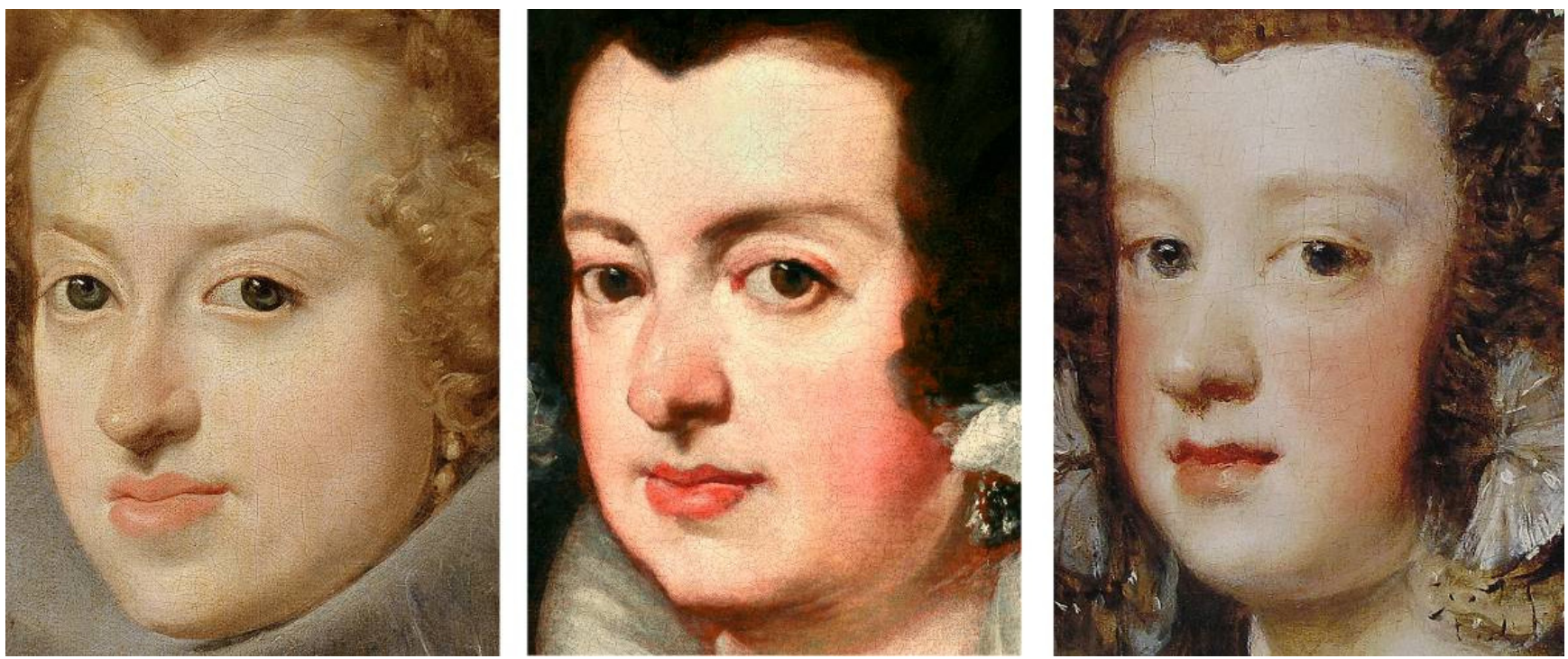

Figura 9. Comparación de los rostros de María de Hungría, Isabel de Borbón y María Teresa. Véanse las semejanzas de toques de luz (en los lagrimales, en la nariz en la boca o rodeando el ojo sobre la mejilla) y de sombra (en el cuello, bajo la nariz y la boca, etc.), el perfilado de la boca, los toques en las comisuras, el trazado en dos momentos de las cejas y el recto trazo que señala el perfil de la cara en el lado derecho, partiendo de debajo del ojo. En los tres casos, la manera de encajar el rostro y el pelo es muy parecida 
la boca; al igual que las demás sombras están pintadas de forma suave. A pesar de ello nos transmiten su existencia, sobre todo en el cuello, aunque esta es una zona menos terminada. Pero el efecto que producen resulta muy velazqueño (Fig.9).

El pintor ha captado con frescura la imagen y la expresión del rostro ya que, al ser un prototipo y estar tomado del natural, resulta más realista. Por otra parte, lo mismo que sucede en otras obras del pintor que quedaron en este nivel de acabado, el trabajo hecho hasta ese momento sugiere todos los detalles, y al contemplarlo a cierta distancia la idea de la representación se completa en nuestra retina, pareciendo terminado el conjunto.

En los modelos pintados por Velázquez para la ejecución de obras de mayor tamaño, por lo general retratos, ocurre algo semejante. Entre ellos se encuentran Maria de Austria, reina de Hungría (Museo del Prado), El Príncipe Baltasar Carlos (Gallería Carrara de Bergamo) (Garrido 1992), El retrato de una niña (The Hispanic Society of America, Nueva York), el de la Reina Mariana (Meadows Museum, Dallas), los dos antes mencionados de la Infanta María Teresa (Metropolitan Museum, Nueva York) o el de Felipe IV de busto (Museo del Prado, Madrid), de muy distintas dataciones a través de su carrera artística y con niveles de trabajo diferentes, a pesar de estar considerados todos como estudios del natural (Fig. 10). Al ser examinados de cerca se puede comprobar que no están "finitos", pero en la distancia todo se suma envolviendo la figura que nos parece terminada, ya que hasta el menor trazo indicativo de dibujo o realce nos permite imaginar cómo será el resultado final, al sugerirnos todos los detalles de la imagen. Por ser modelos, la cabeza es lo más trabajado por el artista para captar las facciones, la expresividad y el alma del personaje, mientras que en el inicio del cuello y el busto la pintura se va deshaciendo, ya que lo demás no le resulta necesario. Para el resto, no posa el personaje pues el pintor lo puedo componer libremente en el taller ${ }^{5}$.

Volviendo a los documentos técnicos, el borde derecho del rostro de la Reina esta perfilado dejando ver una fina línea rojiza que es debida al color de la imprimación, al igual que en todo el contorno de la cara y en el resto de la obra. En el centro bajo la gola, sobre la que Velázquez aplicó una base blanquecina y unos toques más intensos con albayalde para marcar los pliegues, esta imprimación queda al aire, aumentando su presencia en el lado izquierdo y hacia el fondo, como en la zona inferior.

En el traje se han superpuesto pequeños toques y pinceladas que insinúan las decoraciones y adornos de los realces bordados de la tela, y la imprimación juega, lo mismo que en el resto, como un color más que se suma al cromatismo general de la pintura, incluso con mayor presencia que los detalles sugeridos. En algunos de los painted quite softly like the shadows elsewhere in the portrait, they are nonetheless convincing, particularly in the neck even though this is a less finished area. However, the effect they produce is typical of Velázquez (fig. 9).

The artist has captured the features of the sitter and her facial expression with great immediacy, such that it appears more lifelike, as is to be expected in a prototype painted from life. On the other hand, as also occurs in other paintings by the artist that are brought to the same degree of completion that we see here, the work done up to this point already conveys all of the relevant details of the subject, and, when viewed from a certain distance, the image completes itself in the eye of the viewer and thus appears fully finished.

Something similar occurs in the studies painted by Velázquez for larger-scale compositions, which for the most part are portraits. These include the Portrait of María of Hungary (Museo del Prado, Madrid), Portrait of Prince Baltasar Carlos (Accademia Carrara, Bergamo) (Garrido 1992), Portrait of a Girl (The Hispanic Society of America, New York), Portrait of Queen Mariana (Meadows Museum, Dallas), Portrait of Philip IV, bust-length (Museo del Prado, Madrid) and the two previously discussed depictions of the Infanta María Teresa, both in the Metropoli$\tan$ Museum of Art, New York (fig. 10). Although they may all be considered studies from life, these works were painted at different points in the artist's career and executed to varying degrees of finish. When examined from close-up we can see that they are not 'finished', but from a distance everything comes together in the creation of the figure, such that it appears complete. Even the smallest stroke of the preliminary sketch or touch of light allows us to imagine what the final result will be, and in this way every detail of the subject is transmitted to the viewer. Because these works are studies, it is the head of the sitter that the artist has worked up most in order to capture the facial features, expressiveness and soul of the individual, whereas the base of the neck and the chest are painted more loosely, given that there is no need for anything more detailed here. For the rest of the portrait, the sitter did not pose for the artist, who could subsequently finish it in the studio ${ }^{5}$.

Returning to the technical analysis, one can see that the edge of the Queen's face is defined by a thin reddish line where the imprimatura has been left exposed. The same feature can be seen around the head and elsewhere in the painting. In the centre below the ruff, where Velazquez has applied a whitish base layer with some more emphatic strokes of lead white to define the pleats, the red of this priming layer has also been left uncovered, more so on the left side and towards the background, and likewise in the lower half of the picture.

In the costume, small overlapping strokes and touches of colour suggest the decorations and adornments of the embroidered trimmings of the fabric. The red of the imprimatura functions - as it does elsewhere - as another colour in the overall palette of the painting, but with greater emphasis in the specific areas described above. In some of the afore- 

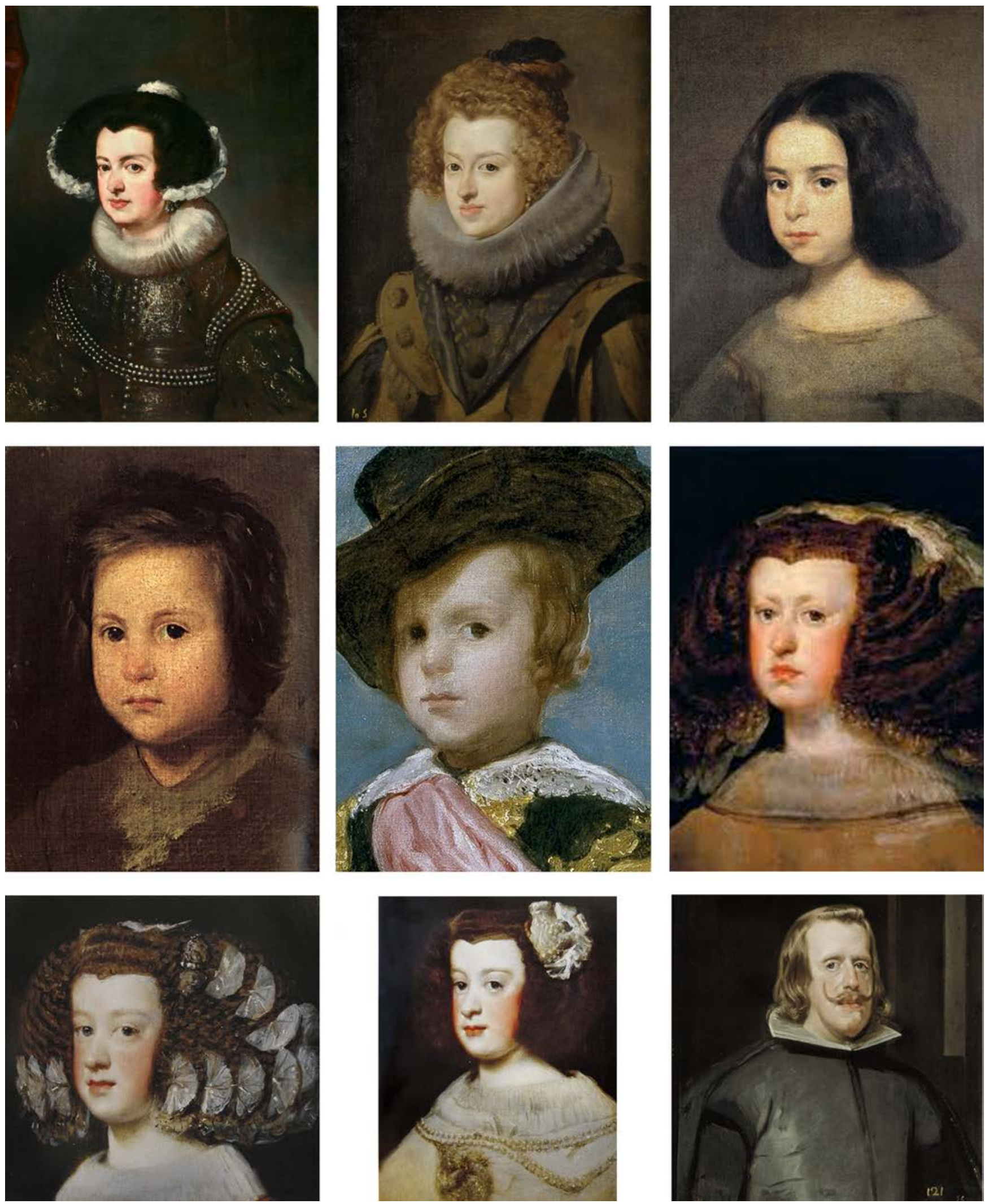

Figura 10. Obras consideradas como bocetos de Velázquez para pinturas de gran tamaño. 
estudios antes mencionados, por ejemplo en el del Retrato de niña de la Hispanic Society, sólo se sobrepone a este estrato de base los trazos de dibujo del patrón del vestido y algo de blanco manchado que sugiere una especie de muceta. De similar forma, en el Retrato de Baltasar Carlos de la Carrara o en el Felipe IV del Museo del Prado aparecen únicamente las líneas negras que delimitan los espacios de la forma del traje y unos toques de luces sobre el tono inicial de la tela. En otros bocetos, como el de la Reina María de Hungría, la gola y el vestido tienen una mayor definición, porque el pintor ha querido dotarle de un nivel de acabado mayor.

En la imagen forzada de color, antes mencionada, se constata la presencia de la tonalidad rojiza de la imprimación por todas partes, salvo en el rostro, por ser esta la zona más trabajada, como corresponde a un estudio previo. En la radiografía y en la reflectografía infrarroja también apreciamos su existencia en los contornos, en las zonas del traje menos decoradas y en el fondo del cuadro, porque al no tener pintura encima o sólo ligeras capas traslúcidas, aparece una línea, y zonas más oscuras, debido a la densidad diferente de la materia en esas partes del retrato. La complementariedad de las imágenes técnicas es fundamental para esta lectura.

La obra está pintada sobre un soporte de lienzo de tafetán que tiene, por $\mathrm{cm}^{2}$, 9-10 hilos en urdimbre por 7-8 pasadas en la trama. Los bordes de este soporte están cortados por el anverso, lo que no han permitido determinar la naturaleza de la tela. La reducción de la tela, tomada a través de la radiografía, está dentro de los parámetros de las empleadas por Velázquez en torno a la época de los primeros retratos del rey y de su hermano Don Carlos (1626-1628), así como de los estudiados en otras obras (Garrido 1992). Aunque el soporte haya sido cortado en los cuatro lados al reentelarse, las dimensiones del cuadro no debieron ser mucho mayores, ya que las ondas de tensión surgidas en todo el perímetro al ser clavado el lienzo sobre el bastidor original, se observan en la radiografía, especialmente en la parte superior.

En los cortes estratigráficos realizados, existe una preparación-imprimación que aparece en otras obras de la misma datación, en torno 1628 (Garrido 1992). En la escena de Los Borrachos del Museo del Prado, hay sólo esta única capa que le sirve al pintor tanto para preparar el lienzo tras encolarlo, según los métodos tradicionales, como para realizar el fondo óptico que sustentará la pintura. La presencia de un solo estrato ha sido encontrada también en el retrato de El inquisidor Don Sebastián de Huerta, recientemente redescubierto, y es de tonalidad anaranjada, igual que la empleada por Velázquez en sus obras de la etapa madrileña y descrita con la denominación de Tierra de Esquivias (óxidos de hierro mezclados con un poco de calcita, blanco de plomo y negro carbón con óleo como aglutinante)(Garrido 1992).

Los materiales de pintura empleados por Velázquez para la ejecución de este retrato son pocos y las mezclas muy sim- mentioned portrait studies, such as the Portrait of a Girl (The Hispanic Society of America, New York), lines sketching out the pattern of the clothing or strokes of white that suggest a cape are all that are painted over this base layer. Likewise in the Portrait of Prince Baltasar Carlos in the Accademia Carrara, Bergamo, and the Portrait of Philip IV, bust-length (Museo del Prado, Madrid), there are only black lines denoting the basic design of the costume and a few highlights applied to the priming layer. In other sketches, for example, in the Portrait of Queen María of Hungary (Museo del Prado, Madrid), the ruff and dress are more defined since the artist wanted to achieve a greater degree of finish.

In the digitally modified image of the portrait mentioned above, the reddish tonality of the priming layer is evident throughout, with the exception of the face since this is the most worked-up passage, as is to be expected in a preliminary study. In the x-ray and infra-red reflectogram, it can also be seen in the outlines, the less finished passages of the costume and the background of the portrait, and, since there is either no paint or just thin translucent glazes in these areas, one can see lines or darker areas because of the different density of material here. The concordance of the technical analyses in this regard is fundamental in our reading of the picture.

The portrait is painted on a taffeta canvas with a thread count of 9-10 threads per $\mathrm{cm}^{2}$ in the vertical direction and 7-8 in the horizontal. The edges of the canvas have been cut from the front, and as a result the original dimensions cannot be established. The thread count, which can be measured in the $x$-ray, is consistent with canvases used by Velázquez when he was working on his first portraits of the king and his brother Don Carlos (1626-1628), as has been seen in paintings studied elsewhere (Garrido 1992). Although the canvas was cut on all fours sides during relining, it cannot have been much larger since the cusping around the edges caused when it was placed on the original stretcher, is evident in the x-ray, particularly along the upper edge.

In the cross-sections taken, one can see a preparatorypriming layer that is found in other works from the same date, circa 1628 (Garrido 1992). In Los Borrachos or The Feast of Bacchus (Museo del Prado, Madrid), the artist has used just one such layer to prepare the canvas, after sizing it with glue in the traditional manner, to create the optical ground that will support the paint. There is also just a single preparatory layer in the recently rediscovered Portrait of the Inquisitor Don Sebastián de Huerta, and its reddish-orange tonality is the same as that used by Velázquez in works from his Madrid period. Known as 'Tierra de Esquivias' or 'Esquivias earth', it consists of iron oxide mixed with a little calcium carbonate, lead white and carbon black and bound with oil. (Garrido 1992).

In the present portrait, Velázquez has used only a few pigments, very simply mixed. This is typical of the artist who 
ples, hecho que es habitual en la obra del pintor, que con el dominio técnico que le caracteriza sabe crear una amplia gama cromática partiendo de lo esencial (Fig. 10). En muchas de las pinceladas blancas, el albayalde está aplicado directamente, como sucede en el tocado de este color en torno a su cabeza, en las zonas más luminosas de la gola y en los toques rápidos e igualmente lumínicos del traje y las perlas. De ahí su fuerte contraste radiográfico, ya que el pincel va más cargado de materia en aquellas zonas en las que hay que realzar la intensidad de la luz. Lo mismo sucede con el negro de origen orgánico en muchos de los trazos y toques dados en dicho tono en el peinado y en los elementos decorativos del vestido, aunque en este caso es la luz infrarroja la que los hace destacar, ya que carecen de respuesta radiográfica.

Existen en el cuadro otros dos elementos frecuentes en la obra de Velázquez que se observan con mayor nitidez en el documento radiográfico. El primero es el halo más claro que rodea la cabeza de la Reina, que queda al aire en ciertas zonas, y en otras se le superpone el tocado mediante toques rápidos que se van sumando, en los que el pincel juega en todas direcciones, creando un movimiento de gran belleza expresiva. Una zona de claridad también se crea a los lados del blanco cuello y en la caída del borde izquierdo del traje, por ser este lateral el que recibe mayor iluminación. Este recurso de clari- was capable of creating a broad palette of colours from quite basic elements - the result of the technical mastery that characterises his oeuvre (fig. 11). In many of the brushstrokes of white pigment, the lead white is applied directly, as can be seen in the headdress, in the brightest passages of the ruff and in the rapidly executed highlights of the costume and pearls. This creates a strong contrast in the x-ray since the brush is more heavily loaded in the areas that require greater highlighting. The same contrast can be seen with the organic black used for many of the dark lines and strokes in the hair and decorative elements of the dress, although in this instance it is the infra-red reflectogram that reveals this given the lack of radiopacity of the black.

The x-ray reveals more clearly two other features often found in works by Velázquez. The first is the 'halo' or circle of light around the Queen's head. In some sections, it is left exposed, whereas in others it is covered by the headdress, which is created through the build-up of rapid brushstrokes. Here the brush flows in every direction, creating a movement of great expressive beauty. There is a strip of light on either side of the white collar and also down the left edge of the costume, since this side is more strongly illuminated. This serves to create the illusion of space bet-
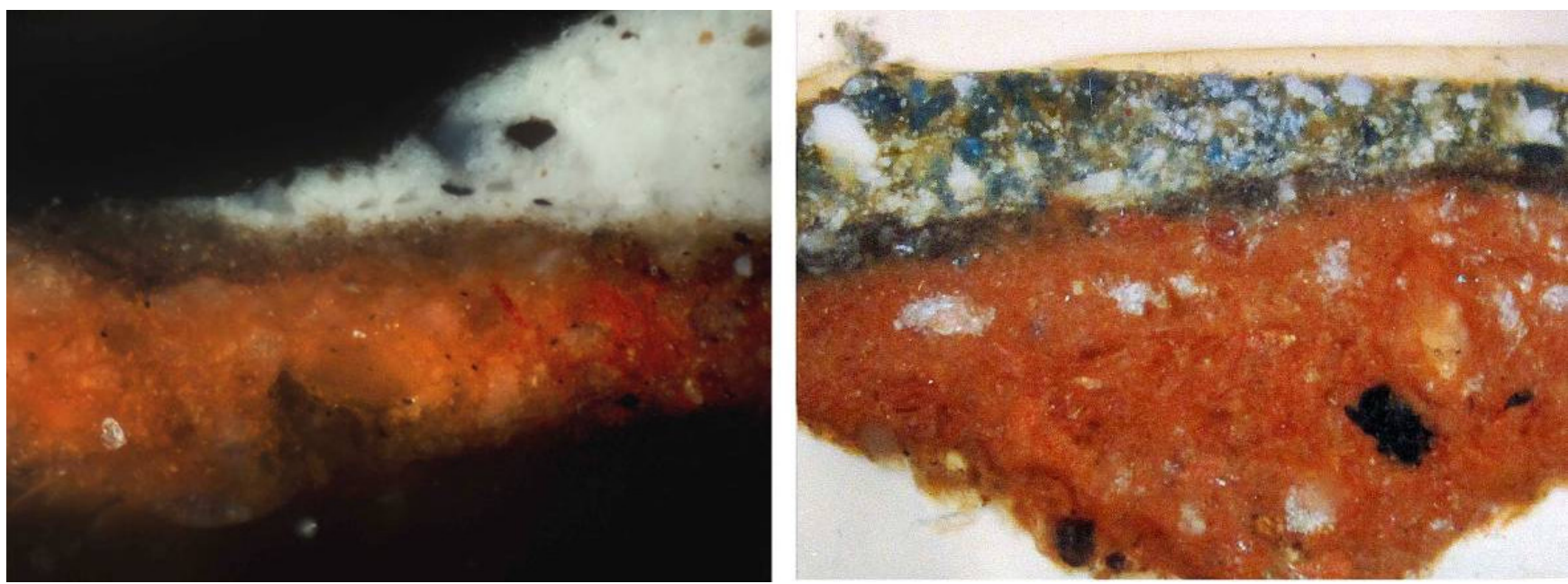

Figura 11. Cortes trasversales sobre micromuestras de pintura. A la izquierda, el de la Reina y a la derecha el de Los Borrachos

dad hace que se cree un efecto de espacio entre la figura y el fondo, que la hace salir hacia el exterior, mientras que la oscuridad hace profundizar la figura en el lado derecho. (Fig.11).

El segundo, es la limpieza o pruebas del color que aparecen sobre el ángulo superior derecho de este cuadro, práctica habitual en muchas de sus obras. En este caso, están dadas de similar forma y tienen una grafía semejante a las del retrato de La Venerable Madre Sor Jerónima de la Fuente o el Retrato del Infante Don Carlos, hermano del Rey, ambos en el Museo del Prado. En todos los casos están dispuestas en un lugar parecido, aunque también ween the sitter and background such that the figure advances towards the viewer, while the darkness on the right causes it to recede (Fig. 11)

The second distinctive feature of the present portrait is the series of brushstrokes in the upper right corner of the picture, where Velázquez has either cleaned his brush or tested colours, an habitual practice found in many of his paintings. The strokes found here are similar in form and in style to those in the Portrait of Venerable Mother Jerónima de la Fuente and the Portrait of the Infante Don Carlos, both in the Museo del Prado. In all three works, they are painted in the same place in the canvas, although the strokes 
aparecen de manera más individualizada. Al final quedan al descubierto o se traslucen a través de las ligeras capas de los fondos, al "trepar" hacia la superficie los tonos oscuros por la translucidez natural de su técnica, acentuada a través del tiempo y sumada al desgaste de los últimos estratos del color (Fig.12). themselves are quite individualized in appearance. In the end, they are either left uncovered or show through the thin glazes of the background, as the darker tones of the strokes rise to the surface - the result of the natural translucency of Velázquez's technique and a process which becomes more pronounced over time and with the thinning of the topmost glazes (fig. 12).
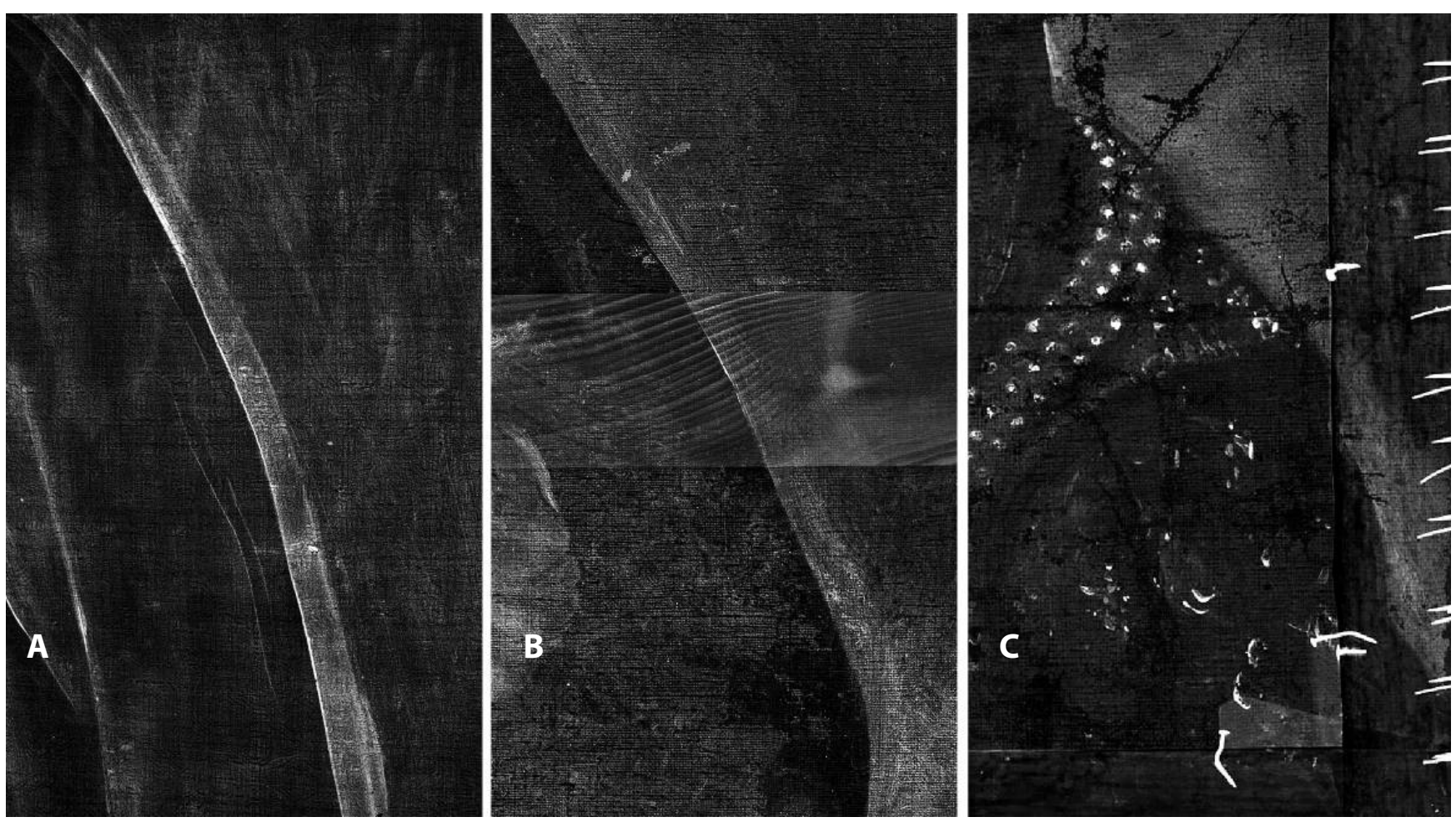

Figura 12. Halos en torno a las figuras: A: La Venerable Madre Sor Jerónima de la Fuente. Museo del Prado.; B: Don Sebastián de Huerta. Colección particular; C: Reina Isabel de Borbón.
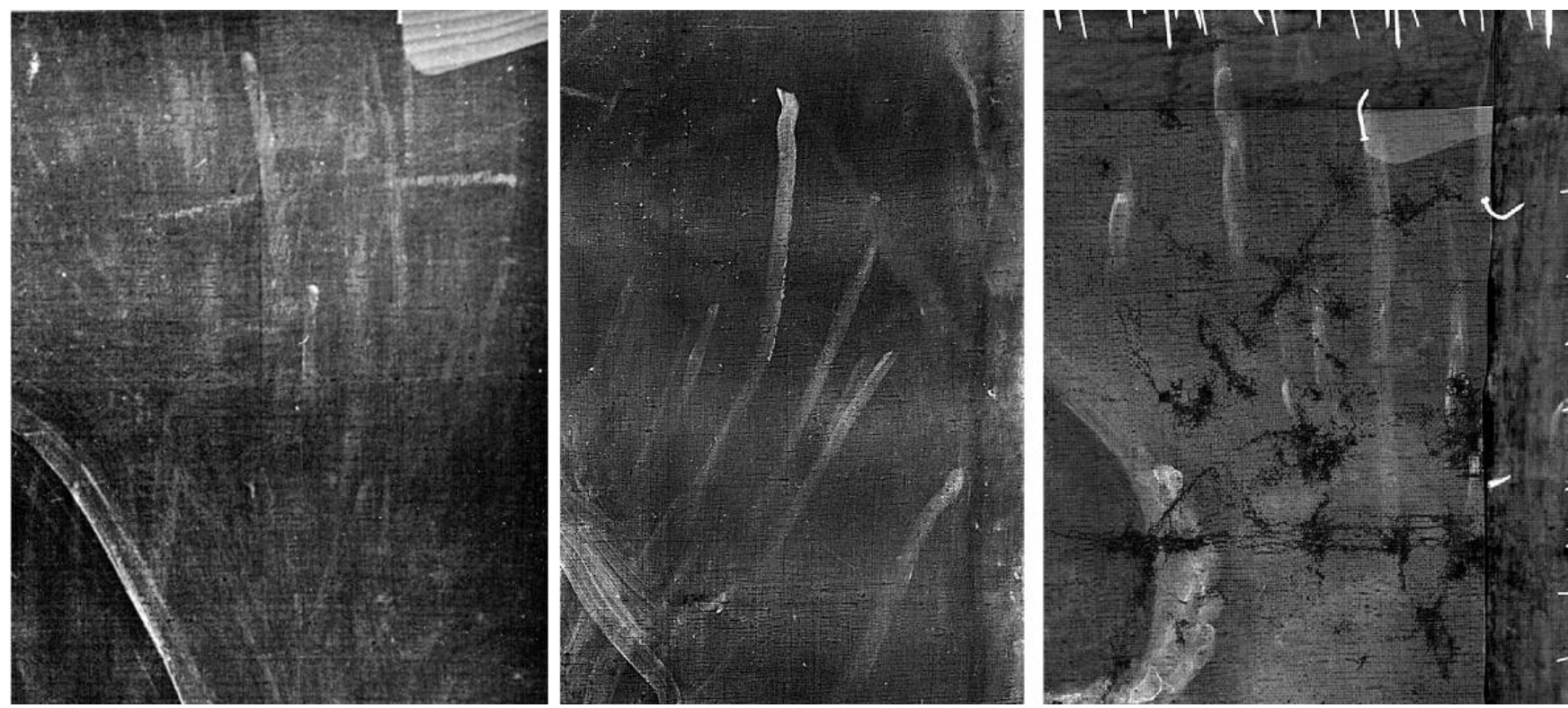

Figura 13. Limpieza o descarga de los pinceles: A: La Venerable Madre Sor Jerónima de la Fuente. Museo del Prado; B: El Infante Don Carlos de Austria. Museo del Prado; C: La Reina Isabel de Borbón 
La cortina colocada en el ángulo superior izquierdo está solamente insinuada, marcándose con un trazo de diseño negro su contorno, y con restregones del mismo pigmento las zonas internas del plegado. En los bordes de los pliegues que sobresalen, ha aclarado la laca roja con algo más de albayalde, pero estos trazos, como sucede en otras partes, son sólo un somero pincelado de la puesta en escena. Todo el contorno de esta cortina está iluminado, al igual que la figura, por medio de un halo blanquecino. En la fotografía publicada por Pantorba en 1960 no se observa este elemento, que estaba tapado por una restauración anterior, ya que en la radiografía se delimita el espacio reservado para ella desde el principio, y en la última restauración ha podido comprobarse la existencia del repinte.

La pintura ha sufrido pérdidas en el transcurso de su historia material. En la radiografía pueden verse con claridad, si bien, por fortuna, éstas no afectan de manera significativa a las partes fundamentales del rostro. Por las líneas horizontales que se marcan sobre el soporte, pensamos que la tela ha podido estar desclavada del bastidor y doblada, lo
The curtain in the upper left corner is just sketched in, its edge defined by a black outline with washes of the same pigment in the folds. Velázquez has lightened the red lake with lead white on the tops of the folds, but the strokes here give only a summary indication of the object they depict, as occurs elsewhere in the portrait. The full length of the curtain's edge is lit with a strip of whitish light, just like the figure itself. The curtain is not visible in the photograph of the portrait published by Pantorba in 1960, as it had been painted over in a previous restoration. In the x-ray, however, the space originally left for the curtain is clearly defined and the overpaint in this area was revealed in the recent restoration.

The painting has suffered some losses over time. These are clearly visible in the x-ray, although thankfully they do not significantly affect the most important passages of the face. The horizontal lines across the canvas suggest that in the past the painting might have been removed from its stretcher and folded, and this would have contributed
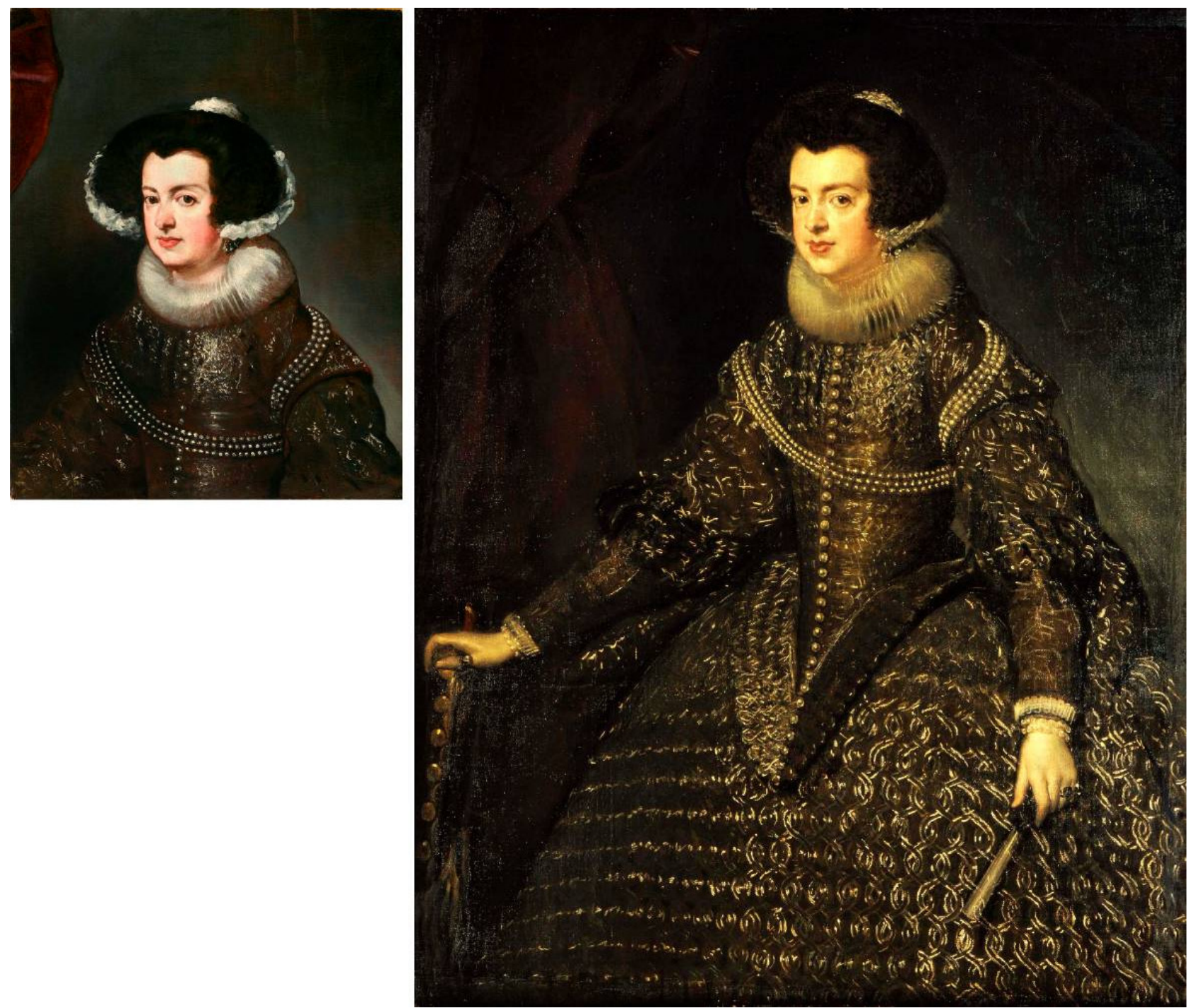

Figura 14. Comparación del boceto de la Reina con el retrato conservado en Viena 
que habría contribuido a los daños que revela. Actualmente, tras un proceso de restauración muy delicado y cuidado, la obra ha recobrado su esplendor, dejándonos ver en detalle la gran calidad que tiene ${ }^{6}$.

La técnica de ejecución del retrato, los materiales empleados y su forma de introducirlos reafirman, a nuestro parecer, la idea de que estamos ante un estudio de la Reina Isabel de Borbón, pintado por Diego Velázquez para la ejecución de otros retratos de Estado que se harían a partir de este modelo realizado del natural, en torno al año 1628, poco antes de su primer viaje a Italia. No se conserva ninguno de cuerpo entero de este momento, aunque es posible que se hiciese lo mismo que el del Rey, el de su hermano Don Carlos, el Conde-Duque o el de otros personajes relevantes de la Corte. Sí se conservan en cambio otros anteriores como el pintado por Villandrando y otros posteriores de Velázquez, además de gran número de copias de menor fortuna de este y otros modelos que realizarían pintores de la corte madrileña.

El que se estudia en este artículo pudo servir para el Retrato de Isabel de Borbón, de tres cuartos, conservado en Viena (Kunsthistorisches Museum, Viena), de mejor calidad que el del Rey con el que se le quiere emparejar, fechados habitualmente en torno a 1632. (Fig. 14). Las pinceladas de la cara y el cuello, así como el halo de luz lateral, o el toque de algunas partes de las decoraciones del vestido recuerdan la grafía y los recursos del pintor, con las diferencias existentes entre un boceto y un cuadro acabado, que pudo tener la participación de algún ayudante. (Fig. 15). to the damages seen. After an extremely careful and sensitive restoration, the portrait has recovered its original splendour, such that we can now see in detail the high quality of the painting. ${ }^{6}$

In the view of the present author, the technique of the portrait, the materials used and the way in which they are used, all confirm that the painting under examination is a study of Queen Isabel of Borbón, painted from life by Diego Velázquez around 1628, shortly before his first trip to Italy, as the model for other State portraits of the Queen. No full-length depiction of the Queen from this period is known, although it is possible that such a work was painted, as was indeed the case with the King, his brother Don Carlos, the Count Duke of Olivares and other figures from the Court. It is true, however, that there are earlier portraits of the Queen by Rodrigo de Villandrando and later ones by Velázquez himself, along with many lesser copies of the present composition and other depictions of the same sitter painted by artists active at the court in Madrid.

The painting under discussion here could have been the model for the three-quarter-length portrait of the Queen now in the Kunsthistorisches Museum, Vienna (fig. 14). Generally dated to c. 1632, it is of better quality than the portrait of the King Philip IV in the same museum with which it is paired. The brushstrokes in the face and collar, the strip of light along the left side figure and the execution of some of the costume decoration recall the brushwork and technique characteristic of the master, albeit allowing for the differences between a fully autograph study and a finished painting which may have involved the participation of an assistant (Fig. 15).
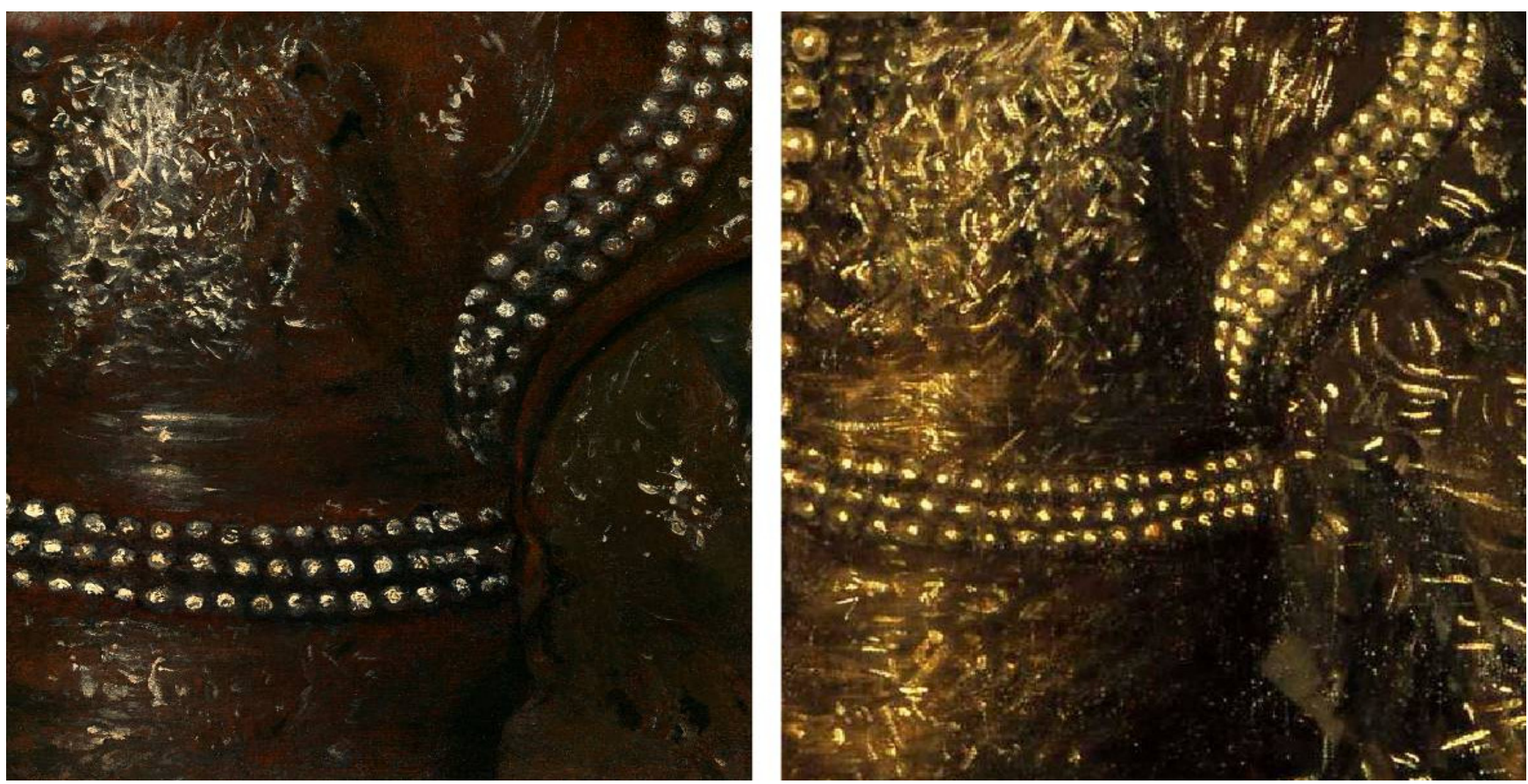

Figura 15. Comparación de las decoraciones de los vestidos de ambos retratos. En el prototipo destaca la simplicidad y limpieza del juego en los brillos de las pinceladas. 
En un retrato de la Reina de cuerpo entero (Col. Particular, Nueva York), pintado tras el viaje a Italia, y que estuvo colgado en el Palacio del Buen Retiro, el rostro se encuentra más idealizado, si bien su radiografía muestra que el punto de partida era una
In a full-length portrait of the Queen (Private Collection, New York; fig. 16) painted after Velázquez's trip to Italy and hung in the Palacio del Buen Ritiro, the face is more idealised, although the $x$-ray image shows that the starting point for the head -
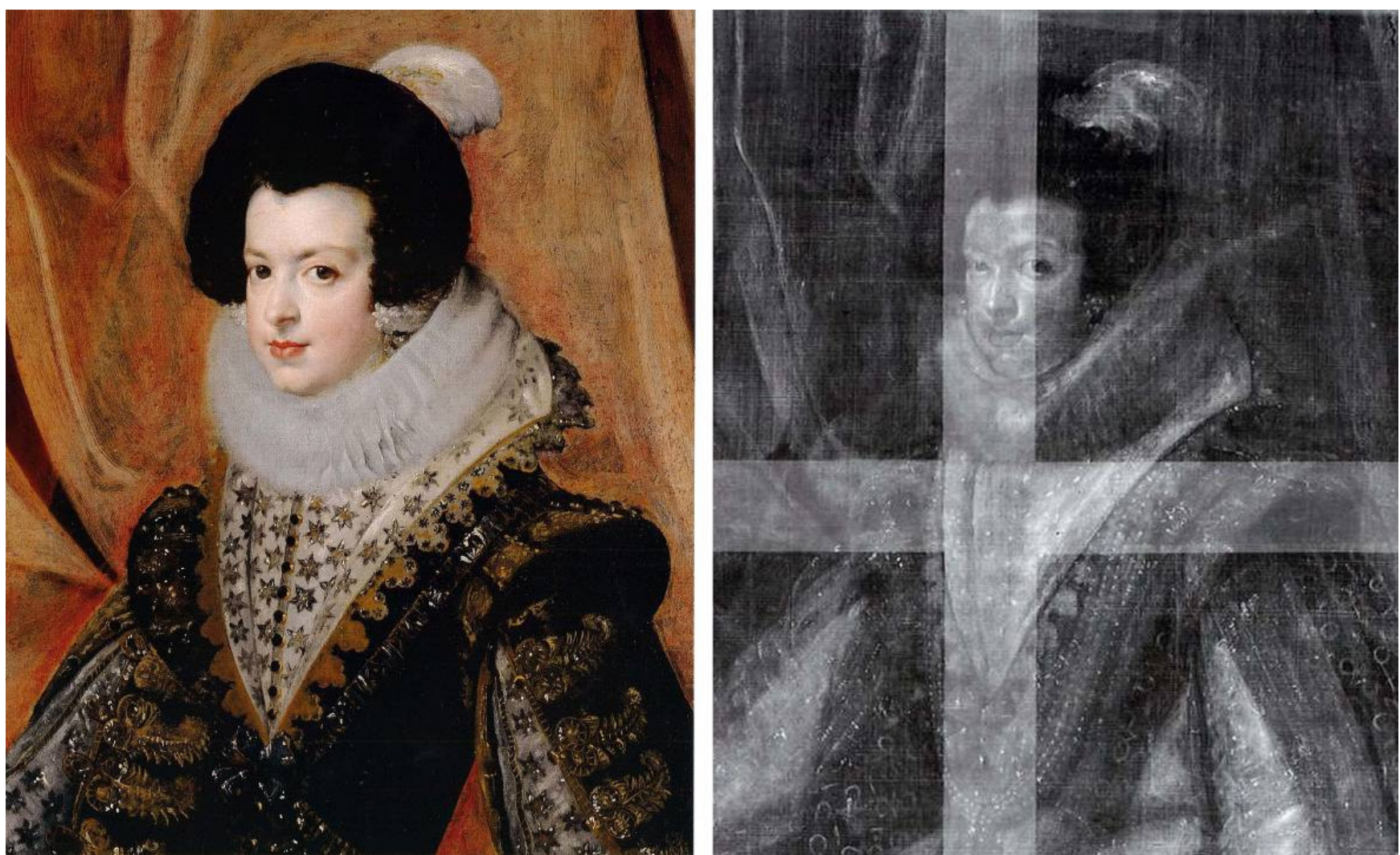

Figura 16. Detalle del retrato de la Reina Isabel de Borbón de una colección particular de New York. Imagen visible y radiográfica.
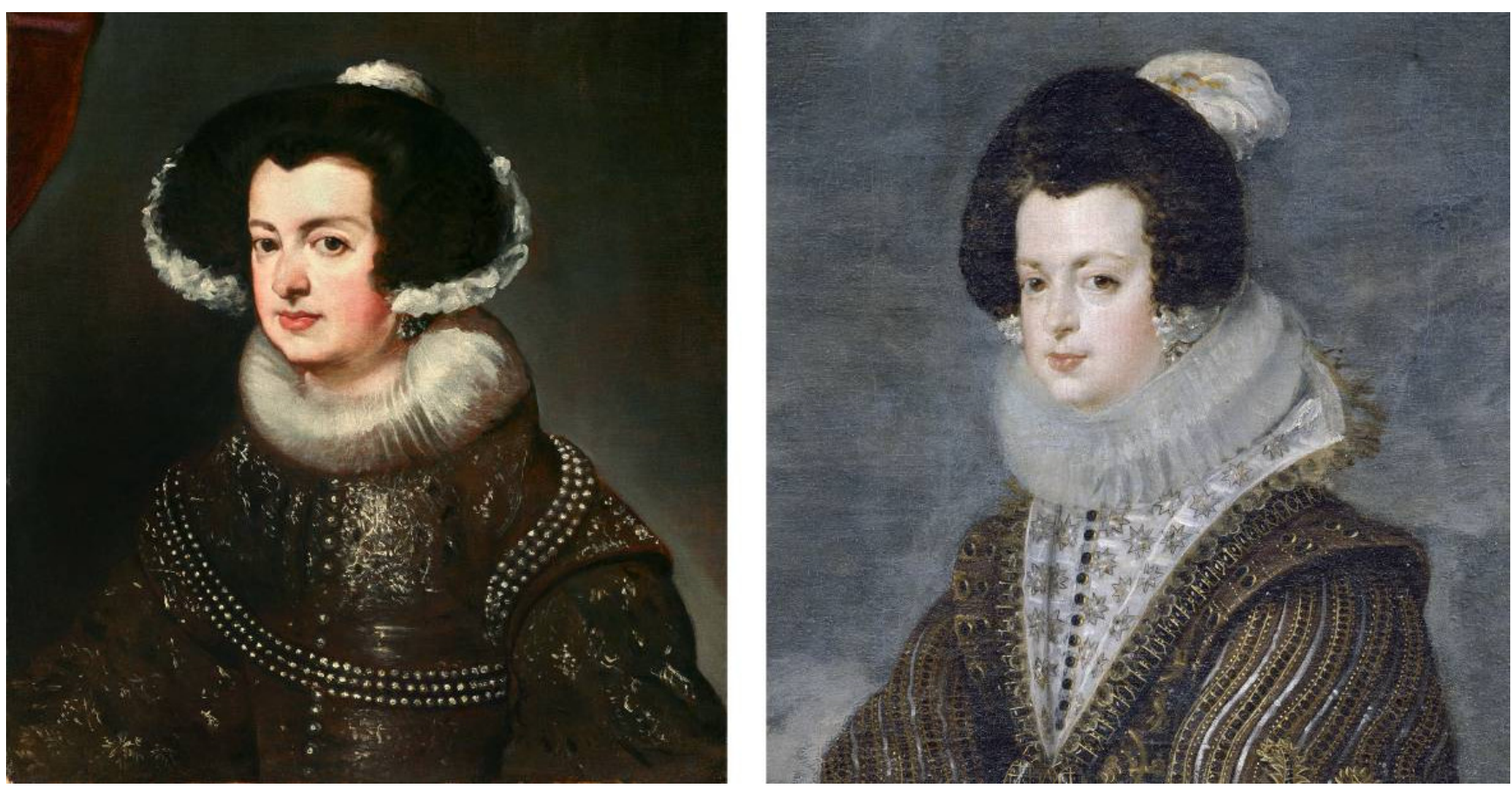

Figura 17. Comparación del boceto de la Reina con la cabeza del retrato ecuestre del Museo del Prado. 
imagen más cercana al boceto que ahora estudiamos, teniendo incluso el peinado semejante en altura. El tocado inicial de la parte superior es muy parecido (Grombie,1958). (Fig.16)

El último retrato de la Reina conservado es el ecuestre pintado para el Salón de reinos del Buen Retiro, ya de mitad de la década de los treinta, cuya cabeza, como otras partes del cuadro fue pintada por Velázquez, manifiesta una evolución técnica de los años transcurridos, así como una idealización aún mayor del rostro. (Fig. 17)

Este redescubrimiento es probablemente el primero y único ejemplo de un estudio del natural de Isabel de Borbón, y una incorporación importante al catálogo de la obra de Diego Velázquez, y claramente cubre un vacío en la producción del artista antes de su primer viaje a Italia.

\section{Notas:}

[1] Sobre este modelo, véase Mayer 1936, Lam. 180, № 477 y 477.

[2] De los personajes que aparecen en el cuadro del Prado, además de los Reyes, el Museo conserva cinco bocetos tomados del natural. Garrido 2002, 287-309.

[3] Los documentos técnicos y los exámenes analísticos del cuadro han sido realizados por el Dr. Nicholas Eastaugh y la Dra. Jilleen Nadolny de Art Access and Research, Londres, Analytical Report. Ref. AAR0215/11 de 25 noviembre 2011.

[4] Para el conocimiento de la técnica del pintor: Garrido, 1992, y Brown y Garrido 1998.

[5] Como sabemos por anécdotas contemporáneas: [...] «hecha que fue la cabeza, para lo restante del cuerpo, por no cansar a la dama, lo trajo a mi casa para acabarlo, que era de medio cuerpo [...]» (Martinez 1988, 211-212). Hecho referido a un retrato femenino pintado por Velázquez en la ciudad de Zaragoza.

[6] La restauración ha sido llevado a cabo por Simon Folkes, Londres. including the height of the coiffure - was closer to the present study. The initial brushstrokes in the hair are also very similar. (Grombie 1958) (Fig.16)

The final depiction of Isabel is the equestrian portrait executed for the Salon de Reinos in the Buen Retiro palace in the mid1630s The head of the sitter, painted along with other parts of the picture, by Velázquez, shows the development of the artist's technique in the intervening years and reveals an even greater idealisation of the face. (Fig. 17).

This rediscovered portrait is probably the first and only example of a study from life of Isabel de Borbón. As such it represents an important addition to the oeuvre of Diego Velázquez and fills a gap in the artist's production before his first trip to Italy.

\section{Notes:}

[1] For this model, see Mayer 1936, pl. 180, nos. 476 \& 477 .

[2] The museum has five studies painted from life for figures in the picture, in addition to those for the King and Queen. See Carmen 2002, 287-309.

[3] The technical analysis was done by Dr. Nicholas Eastaugh and Dra. Jilleen Nadolny of Art Access and Research, London (Analytical Report, Ref AAR0215/11, 25 November 2011).

[4] For studies on the artist's technique see Garrido, 1992, and Brown and Garrido 1998.

[6] As we know from contemporary accounts: "... he did the head but, so as not to tire the lady, he brought the picture, which was a half-length portrait, to my home to finish it ..." (Martinez 1988, 211-212.). This is in reference to a female portrait painted by Velázquez in Zaragoza.

[6] The restoration was done by Simon Folkes, London.

\section{Bibliografía:}

BROWN, J. y GARRIDO, C. (1998). La ténica del Genio. Yale University. Madrid: Ediciones Encuentro.

CROMBIE, T. (1958 ). "Isabella of Bourbon by Velázquez", Connoisseur, 141, 238-244.

DOVAL TRUEBA, M. del M. (2009)."Velázquez y los retratos de Isabel de Borbón", Boletín Museo e Instituto Camón Aznar. №103, 137-157.

GARRIDO, C. (1992). Velázquez técnica y evolución. Madrid. Museo del Prado.

GARRIDO PÉREZ, C. (2002). “Cómo se pintó el retrato de la Familia”, 
en Goya. La familia de Carlos IV. Ed. a cargo de Manuela B. Mena Marqués. Madrid: Museo Nacional del Prado, 287-309.

GARRIDO, C. (2004). “Puntualizaciones sobre algunos retratos de Diego Velázquez". Goya. Revista de Arte, n 298: 4-24.

GARRIDO, C. (2013). "Velázquez y el Inquisidor”, Ars Magazine. Número 17, enero-marzo: 56-68.

MARTINEZ, J. (1988). Discursos practicables del novilísimo arte de la pintura. Madrid: Akal.

MAYER, A. L. (1936). Velázquez. A Catalogue Raisonné of the Pictures and Drawings. Londres, Faber and Faber, Limited.

OLIVÁN SANTALIESTRA, L. (2012). “Decía que no se dejaba retratar de buena gana". Modestia e invisibilidad de la reina Isabel de Borbón (1635-1644)", en Goya. № 338: 16-35.

PACHECO, F. (1990). El Arte de la Pintura [1649]. Madrid: Ed. Cátedra.

PALOMINO, A. (2008). Vida de Don Diego Velázquez de Silva [1724] Madrid, Ediciones AKAL.

PANTORBA, B. de (1960). Sobre un retrato de la reina Isabel de Borbón, Madrid.

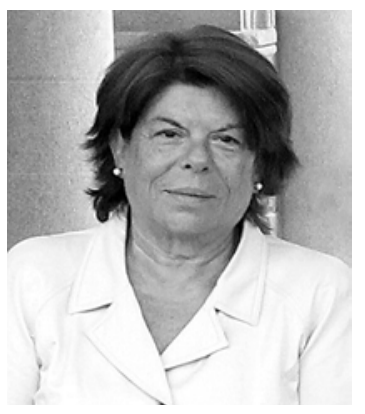

\section{Carmen Garrído Pérez}

carmengarridoperez@gmail.com

Doctora en Historia del Arte, especializada en la aplicación de los métodos de laboratorio para el estudio de la Historia del Arte, el conocimiento del proceso creativo de los artistas y las técnicas pictóricas, y los exámenes del estado material y la conservación de las obras.

Después de trabajar en el Laboratorio del Instituto de Conservación y Restauración de Madrid (actual IPCE) y en la Escuela de Restauración del mismo Centro, se incorporó en 1978 al Museo Nacional del Prado para llevar a cabo el montaje y el desarrollo del Gabinete de Documentación Técnica, del que ha sido responsable hasta 2013.

Entre sus más de ciento cincuenta publicaciones cabe destacar los libros de Velázquez: Técnica y Evolución (1992), Velázquez: La técnica del genio (1998) en colaboración con el profesor Jonathan Brown, El Bosco en el Museo del Prado: Estudio Técnico (2001) en colaboración con el profesor con Roger Van Schoute y otros profesores, Luis Meléndez. La serie de los bodegones del Príncipe de Asturias: Estudio Técnico (2004) con el profesor Peter Cherry. A finales de este año saldrá publicado su último libro, El Greco pintor. 